\title{
The Circumstantial Media Activist: An Analysis of the Relation between Media and Political Representation
}

\section{Paola Sartoretto}

To cite this article: Paola Sartoretto (2016) The Circumstantial Media Activist: An Analysis of the Relation between Media and Political Representation, Javnost - The Public, 23:3, 273-289, DOI: $10.1080 / 13183222.2016 .1210466$

To link to this article: $h$ ttp://dx.doi.org/10.1080/13183222.2016.1210466

曲 Published online: 19 Sep 2016.

Submit your article to this journal $\square$

Q View related articles ¿

View Crossmark data ¿ 


\title{
THE CIRCUMSTANTIAL MEDIA ACTIVIST: AN ANALYSIS OF THE RELATION BETWEEN MEDIA AND POLITICAL REPRESENTATION
}

\section{Paola Sartoretto}

\begin{abstract}
Alternative or radical media are kinds of media production common among social movements whose members do not see their causes represented in mainstream media. This is the case of the Brazilian Landless Workers Movement (MST), which since 1984 has created media outlets and produced content for different platforms, later becoming active in the area of media and communication rights in Brazil. Based on fieldwork carried out in 2013 and 2014, this article proposes that a perspective of communication rights is attentive to the structural configuration of the media landscape and not only to the provision of technology and production skills. This study shows that collective action and promotion of structural change are still relevant alongside new technologies.
\end{abstract}

KEYWORDS media activism; communication rights; representation; participation; social movement

\section{Introduction}

Although there is documentation of alternative and counter-hegemonic news media and journalism dating back to the nineteenth century (Atton and Hamilton 2008, 16-17), the term media activism is more specifically associated with contemporary media initiatives (Milan 2013). From the late twentieth century, media production outside institutionalised media corporations intensified in many parts of the world (see, for instance, Atton 2002). These included fanzines and underground publications, activist media, community radios and alternative video production. There are many different (and sometimes conflicting) notions of alternative media, ${ }^{1}$ which can also be called "radical media" (Downing 2000), but one common denominator among these definitions is the commitment of alternative media to collective production, democratic participation and the rights of minorities and subaltern classes to self-expression (Gumucio-Dagron 2001; Rodriguez 2003). Alternative media outlets also respond to and materialise demands for representation among different groups. Consequently, activists' and social movements' media production is by default alternative in the sense that it is a form of self-representation; it is usually collectively produced and has a non-commercial ethos. ${ }^{2}$

In this article I address activist media as a particular category of alternative media and discuss the interplay between social mobilisation and media activism. But what sets media activism aside from other forms of activism? One simple answer is to say that media activism focuses on media demands, aiming to reclaim or gain control over media as a 
means of communication, circulation of content and representation. Milan (2013) cites networked digital activism, community broadcasting and tech activism as forms of media activism. Media activism can sometimes mean the simple action of using different media to call attention to social problems and issues affecting certain groups; it can also include the creation of alternative media outlets and channels (Zhao 2003) and, on a more structural level, it can include actions that aim at changing the structure of the media landscape.

Media activism arises from a realisation that dominant, mainstream or hegemonic media do not represent the plurality of groups and interests in a given society and consequently cannot be arenas in which problems and issues that affect minority and marginal groups can be discussed. Media activism can also demand and act against surveillance, promoting access to secure spaces for discussion and information exchange (Milan 2013). Such issues have been discussed in international arenas since the 1980s, culminating in the publication of the UNESCO report "One World, Many Voices" and continuing later with the World Summits on the Information Society in 2003 and 2005. Already in the first report it was noted that much effort was put on granting rights to receive information while not much was done to grant the right to produce and circulate messages. This kind of imbalance affects especially rural and indigenous populations around the world, many of whom live in countries where media are essentially commercial enterprises and ownership is concentrated in the hands of a few corporations. This is the case in Brazil, where 30 families $^{3}$ dominate national and regional markets. As a result, rural and indigenous populations have sub-standard access to communication and do not have the opportunities to raise questions that are relevant to them in the media. In this context, my aim is to highlight the crucial role of media in processes of social mobilisation, representation (Fraser 2009) and political participation. ${ }^{4}$

At the same time I argue that even with the emergence of digital networks and digital social media, political economic aspects still structure the distribution of symbolic power through media. Sharing Fuchs and Sandoval's $(2010,141)$ statement that we should not be too optimistic about the "actual democratic effects" of alternative media, I intend to provide empirical evidence on the relevance of political economic and structural aspects for the democratisation of media. In recent years, media activism has become a particular area of activism in itself, as communication rights become a demand in par with other historical issues such as environmental, gender-related and human rights (Peruzzo 2014).

In order to address the questions highlighted, I discuss the case of the Brazilian Landless Workers Movement (Movimento dos Trabalhadores Rurais Sem Terra [MST]), one of Latin America's biggest social movements, with over 30 years of activity and around 1.5 million members. MST was founded as a class-based organisation aiming to promote redistribution of land in Brazil through agrarian reform. MST's main form of action is occupation of land that does not fulfil its social function according to Brazilian agrarian law-thus being subject to expropriation-and subsequent construction of camp-sites that may become settlements if land ownership is granted to the occupiers. Since it was founded in 1984, MST has directed focus to the creation of media outlets, of which the movement's newspaper Jornal Sem Terra and the settlement radios are examples. However, MST militants realised at an early stage that the concentration of media ownership and the insidious relations between landowners, politicians, agribusiness corporations and the media had to be tackled. Since then MST has been acting in the area of media democratisation in Brazil, becoming a member of the National Forum for Democratization of Communication (FNDC), and actively promoting media democratisation and communication rights in 
parallel with land reform. The analysis of MST's crescent involvement with media activism is carried out through interviews and observations performed during fieldtrips in 2013 and 2014. A total of 22 interviews and fieldwork diaries from visits to settlement radios, press offices and one school as well as participation in MST's national congress in 2014 are used to discuss questions concerning the roles and significances of media for social movements.

Using the case of MST, I argue that communication rights (Deane 2007; Peruzzo 2007) are central to marginal and counter-hegemonic organisations. It is only when these organisations are granted communication rights that they will be represented, in Fraser's (2009) terms. The analysis also questions the idea that communication rights are achieved through the provision of technologies that enable and facilitate communication. On the contrary, the interviews point towards a much more complex relation between media, communication and representation in the public debate. Through the analysis of MST's work as a media activist organisation on the side of its main area of concern, we can add new angles to the discussion of the relations between media and collective political participation. As an established social actor in Brazil and Latin America, MST's experience can point to new directions for the assessment of opportunities and challenges in securing political participation for minorities and marginal groups.

This article is divided into four sections and a conclusion. The first section presents a brief panorama of research and theorisation on activism and media activism, problematising the recent technological bias that permeates analysis of activist and protest action. The following section presents the methods and materials utilised in the research. The last two sections analyse the results from two perspectives-I discuss the process through which MST became a "circumstantial media activist" and I propose a view of media participation and representation beyond technological determinism.

\section{On Media Activism, Representation and Participation}

Protest organisations and activists have since long realised the importance of media for the achievement of their goals and for advancing demands to the status of public debate issues (Halloran, Elliot, and Murdock 1970; Gitlin 1980; Rodríguez 2001; Wolfsfeld 2004). Broadly speaking, media practices enacted by activist organisations can be divided into two main areas: construction of their own arenas that are aimed for communication between activists and as an alternative to mainstream media institutions; and development of relations with mainstream media institutions in order to advance their issues to a wider public. With the development and spread of new technologies that facilitate self-publication and circulation of content, the construction of new communication arenas has gained prominent space in research agendas (see, for instance, Rodríguez 2011; Bennett and Segerberg 2012). Moreover, with arising problems and issues brought by the development and widespread of digital media (surveillance, access to technologies that become ever more necessary, censorship), communication rights (see Milan 2013) have become an area of activism in themselves.

It is thus fair to argue that communication is a site of struggle (Milan 2013), which means that power and resource asymmetries force certain groups to resort to organised activity in order to change their position and the general allocation of resources in the field. But if communication is a site of struggle, what exactly is the object of struggle? 
We can begin answering this question by looking into what resources and what kinds of power are so asymmetrically distributed that organised action is needed to change this structure. One short answer is that communication power is the object of media activists' struggle.

Castells (2009) argues that communication power is a decisive element in social change processes because it is crucial to start other processes such as surveillance and censorship. It then follows that whoever exerts communication power has the possibility to dominate other sectors in society. Thus, Castells (2009) sees new digital communication technologies as potential instruments of social change because new technologies are more accessible to those lacking material resources with which to exert communication power. Couldry (2012) highlights "major uncertainties" generated by Castells' analysis of network power. He contends that power is exerted socially, beyond the materiality of technologies, even though it materialises in the practices of using, producing and consuming media. This proposition diverts the focus of analyses from the descriptive usage of technologies to the social practices that surround them, seeking to devise normative ethical theories of media. This resonates with Fraser's (2009) view of transnational justice as being concerned with recognition, redistribution and representation.

Fraser explains $(2009,6)$ that representation accounts for situations when some subjects-who are already counted as members in a society-cannot participate as peers in social interaction. Even though Fraser never discusses media or the role thereof in this process, the field of media studies teaches us that political and symbolic representations materialise in the media in different ways, provided we agree that social interaction is becoming increasingly mediated. Insofar as media constitute, in conjunction with other institutions, the arenas where representation materialises, it is necessary-as Couldry proposes - to discuss an ethics of media.

Drawing on Fraser's (2009) conceptualisation, it is possible to say that representation (being it of groups, issues or problems) is at the core of most direct action. It follows that activists in general use different forms of media in many ways in order to draw the attention of the public to themselves and their issues directly or through institutionalised media (Gaber and Wilson 2005; de Jong 2005; DeLuca, Sun, and Peeples 2011; Gavin and Marshall 2011). In the last two decades, as media and technologies of communication become more central to life in general, media activism also moves towards the provision of technology for those who do not have access to it and towards the struggle against surveillance exerted by authoritarian governments or states upon citizens. One aspect that sets media activism apart from other areas of activism is that while activists and social movements use media and relate to media as mediators of communication, media activism has a goal to change the structure or flow of communication. The FNDC in Brazil is an example of an organisation working to change the structure of the media landscape in the country. The Forum is a pool of civil society organisations that campaign for a range of issues within the framework of democratisation of communications, such as network neutrality, prohibition of media ownership by politicians and changes in the legal framework that regulates community radios.

Another aspect of media activism is its counter-hegemonic ethos which, drawing on Gramscian terminology (Gramsci 1971), means that actions are directed to counteract hegemonic media and hegemonic groups in society. In the case analysed here, both hegemonic media and hegemonic groups intersect because politicians and elites (local, 
regional and national) own media corporations. This ownership structure grants such groups primacy in interpreting and framing events and issues. For MST this means three different kinds of obstacles to reaching public debate: their own-produced media need to compete for an audience with mainstream media; as an insurgent group they are not a preferred source; and they are class antagonists to the groups in control of large media corporations in Brazil.

In addition to the struggle at the symbolic dimension already described, the development of technologies and the ubiquity of media in all sectors of life-a phenomenon that generated the term mediatisation-have meant that media in their material forms have also become sites of struggle. Up until recently what was at stake was access to relevant information and the right to participate through the media (Carpentier 2007), ${ }^{5}$ or to be represented as a minority in mainstream media channels. However, as communication technologies become essential to many other human activities (accessing state bodies, banking, education, healthcare) and are unequally distributed through different social strata and geographical areas, access to technology also becomes a site of struggle. In certain cases, as will be explored in the following sections, both material scarcity and symbolic misrepresentation are interconnected. Such a relation raises questions about the political aspects that surround the access and use of technologies for political participation. In her discussion of these questions, Peruzzo $(2014,180)$ considers communication a human right to be granted to both individuals and communities or collectives, highlighting the importance of group communication that extends citizenship. She sees community communication not just as a form of self-representation, but also as a way to build political representation in line with Fraser's view.

It has become clear by now that both practice and theory deal with two levels of media activism - the micro level of the group or community that needs to have access to communication rights in order to receive relevant information and to be heard, and the macro level of the political and symbolical representation of these groups in national and transnational public debates that take place in the media. Considering these two levels there is a tendency to focus on the first, for understandable reasons. From an empirical perspective it is far easier to analyse the micro level and the relations between individuals and the group or community to which they belong. It requires more robust empirical efforts to establish and discuss relationships at the macro level, between groups and communities and the macro-structures of which they are part. Although the intersection between political activism, media and participation has been extensively researched, it was mostly done from an endogenous perspective; that is, it looked into social relations within the groups analysed and to their use of media as an end in itself. Taking MST experience as a starting point I will discuss media activism from an exogenous perspective; that is, in relation to other sectors of society. Following Carpentier (2009), this perspective is attentive to the interplay between alternative and mass media in the assessment of participation, seeking to further the analysis by establishing analytical connections between participation and representation.

In order to explore these connections, this study looks into the mechanisms behind the process through which a social movement is compelled to perform media activism. The objective is to explore and gain understanding about the centrality of communication for democratic participation, representation and promotion of diversity in the media. 


\section{Methods and Materials}

This analysis is based on a corpus of 22 interviews with MST militants who are active in the movement within the area of communication in various forms (radio communicators, press officers at national and regional levels, video educators) and on observations of the activities at MST press offices in São Paulo and Brasília, at a settlement radio in the state of São Paulo, at one MST school in the state of Rio Grande do Sul and during the MST's sixth national congress in Brasília. The fieldwork and interviews are part of a doctoral dissertation project that looked into MST's communicative processes. The interviews are from 36 to 120 minutes long and were carried out during two fieldtrips to Brazil in July-September 2013 and February-March 2014. I met with informants at their workplaces and homes, and also at the congress venue during MST's national congress in Brasília. One of the topics discussed during the semi-structured interviews was MST's participation in the FNDC. In the interview, analytical concepts that are related to the dissertation's research questions were used as themes to guide specific questions. These themes were translated into questions (see Table 1) during the interviews, according to the work and experiences of the informant. Since the informants worked with different tasks and activities and had varied responsibilities in the movement, it was not possible to create a script with specific questions that would be relevant to all informants.

Two of the concepts-counter-hegemonic potential of media practices and potential of media as channels for countering dominance-are analysed in this article. Counter-hegemonic potential of media practices refers to how members in MST experience their relations with different media institutions and how they evaluate the potential to challenge hegemony through these media. Potential of media as counter-dominance channels is aimed to encompass the views of MST members about their experiences of building their own media channels and arenas and whether these channels can grant them participation in the public sphere.

All of the interviews were transcribed and coded according to themes related to the dissertation's research questions. As the interviews were carried out in Portuguese, relevant

TABLE 1

Interview cues and related analytical concepts

\begin{tabular}{|c|c|}
\hline Analytical concept & Interview thematic cue \\
\hline \multirow[t]{2}{*}{$\begin{array}{l}\text { Counter-hegemonic potential of } \\
\text { media practices }\end{array}$} & $\begin{array}{l}\text { Discuss expectations, experiences and appreciation } \\
\text { of the outcomes of different communicative } \\
\text { processes and media practices }\end{array}$ \\
\hline & $\begin{array}{l}\text { Learn about members' evaluation of movement's } \\
\text { communicative processes in their potential to } \\
\text { challenge media hegemony }\end{array}$ \\
\hline \multirow[t]{3}{*}{$\begin{array}{l}\text { Potential of media-as channels } \\
\text { for countering dominance }\end{array}$} & $\begin{array}{l}\text { - Discuss possibilities and hindrances associated with } \\
\text { different media channels }\end{array}$ \\
\hline & $\begin{array}{l}\text { - Ask informants to describe their experiences with } \\
\text { different media channels }\end{array}$ \\
\hline & $\begin{array}{l}\text { Discuss the ways in which movement members } \\
\text { experience participation in the public sphere }\end{array}$ \\
\hline
\end{tabular}


parts have been translated into English in order to be used in articles, presentations and the final dissertation. Each one of the themes was then refined in order to find overarching patterns and rationales.

The informants signed an agreement of informed consent that explained how the interviews would be used (in the doctoral dissertation and articles). The agreement also stated that I would not use real names if the informant so wished, but all informants authorised the use of their names. They also had access to the interview transcripts for comments and corrections-only two informants responded to the emails correcting mostly factual data from the interviews.

\section{Becoming a Circumstantial Media Activist-The Centrality of Communication for Representation}

Criticism to technologic determinist and media-centric analyses of political participation and activism has emerged in recent years (Mosco 2005; Morozov 2012; Curran, Fenton, and Freedman 2012; McChesney 2013). In the specific area of alternative communication and media democratisation, the initial celebratory and optimistic tones have slowly been overturned by soberer and more complex analyses of the relation between media, political and symbolic representation and political participation. Based on the findings in this study, I argue that communication rights are crucial to participation that can, in turn, lead to political representation. Communication rights should be understood as the right to a diverse and inclusive media where the full spectrum of opinions and groups that are present in a given society are represented. Thus, the reach of communication rights goes beyond access to technologies. The interviews with MST militants show that communication rights in their view include structural reforms in the media landscape, which would mean that they will be represented in public debate through the media. In this sense, the study provides empirical support to the argument that simple access to media technologies does not automatically lift marginal groups to a position of centrality in the public debate. This is particularly the case in a group such as MST whose members are conscious of their position and can evaluate and reflect upon their achievements as a collective. In contrast, those who engage individually in different forms of digital activism might overestimate or simply fail to reflect upon the results and outcomes of their actions in a wider social perspective.

Within the movement, the production and circulation of messages are not seen as simple actions that naturally unfold whenever communication technologies are available. Communication is considered a collective process that needs to bring benefits to the whole group. The importance of establishing channels of communication and selfexpression was realised in the early stages during the formation of the movement. Itelvina and Solange explain how MST started to construct their own media as ways of selfexpression (Rodríguez 2011) but also in order to mobilise MST's militancy:

[... ] the importance of Jornal Sem-Terra, from its conception at Fazenda Anoni [first MST occupation], which was its origin, the birth of the first printed newspaper that was the origin of Jornal Sem-Terra, is this idea that it was a tool for the movement, a tool for formation and information at the same time [...] made by the workers themselves. Later we started with the idea of having a journalist, editor, chief-editor, but always popular ${ }^{6}$ journalists, connected to the movement and the whole network that started in all states. They 
were then called caretakers of Jornal Sem-Terra and the caretaker was a militant. (Itelvina, member in MST National Leadership)

[...] Jornal Sem-Terra was created in 1981 as a bulletin, it was created even before MST existed officially as a movement, which happened in 1984. The newspaper is one of our main vehicles of communication for the debate and discussion with our basis. The newspaper is thus as a patrimony that we have as a social movement and it contributes in the sense of constructing a national political line, a national organization. (Solange, member in the National Leadership, representing the Communication Sector)

This view of mediated communication as a form of socialisation is supported by constructionist traditions (Berger and Luckman 1967) and symbolic interactionism. The creation and subsequent institutionalisation of the movement newspaper, Jornal Sem-Terra, also reflects the view of mediated communication as a way to "make something common". In this case, the collective production, circulation and consumption of the newspaper contributed to the creation of shared values and of a community of MST militants, geographically spread throughout Brazil. The MST newspaper was not only a medium in the sense that it transmitted messages in a classic communication model (Shannon and Weaver 1949), but it was also a tool for the reproduction of social practices, in line with understanding the media as embedded in social realities (Williams 2003; Silverstone 2007; Couldry 2012). The movement newspaper constituted a national arena for sharing emerging ideas about agrarian reform and rural worker's rights, as well as a medium for political formation within the movement. It was and still is a critical medium (Fuchs 2010) and promotes participation in the media (Carpentier 2011) because the content of the issues is subject to discussion between the movement's base, regional and national leaderships. While the national newspaper functioned as a communication arena for the national membership to share and discuss broader political guidelines, militants in the settlements felt the need to communicate locally and saw in the radio a possibility to strengthen the settlements as communities. In many cases, local radios collaborated with MST by conceding slots in their programming to the movement. In other cases, militants themselves were able to implement rudimentary radio stations broadcasting to the settlement. Miguel, who worked with radio production within MST in the 1990s, told me that sometimes militant could count on supportive catholic priests who would give MST broadcasting slots in their radios. Those radios are seen as an important instrument of mobilisation but also as a medium for circulating information that is relevant for settlement dwellers and that is not covered by local commercial radios. ${ }^{7}$

At the same time MST's activities such as occupations and protests started to gain certain visibility, first locally and later nationally. As national newspapers and television start to report on occupations and demonstrations such as the national march to Brasília in 1997, the relationship between MST and Brazilian media starts to gain its contours. ${ }^{8}$ It is outside the scope of this article to provide a detailed analysis of media coverage about MST and the agrarian question in Brazil. It suffices here to observe that patterns of coverage and framings have changed during MST's 30 years of activity, but the view within the movement is that the large media corporations in Brazil are rural workers' class antagonists because they represent the interests of the elites in the country. ${ }^{9}$ The following excerpts illustrate this understanding:

Brazilian press comes daily to people's homes as though it was something neutral, instead of recognizing "we have a position, we belong to Marinho family, we are Globo Network 
and we at Globo Network and Bandeirantes Network are members in the Brazilian Agribusiness Association." So, how do you watch a news feature defending the interests of agribusiness corporations without knowing that Bandeirantes and Globo are members in the Brazilian Agribusines Association? The movement, independent of our method of action, be it land occupation or giving out candy to children, will always be antagonist to the large media corporations because they are so connected to these sectors, or are themselves large landowners. (Miguel, former press officer)

Hegemonic press, or bourgeois press still determine much of public opinion in Brazil. I say they still determine because since a while back this credibility is being questioned by the movements for democratization of communication, we are denouncing this process of information manipulation. (Mayrá, press officer)

... a while ago we had another position in relation to the press, we used to shut down and not speak to the press, MST hardly ever spoke to the press. We had an understanding, in our basis, that there was no point in speaking to the press because the press were our enemies. However, through the years we started to realize that yes, the press belong to the dominant class, they are our enemies, but at the same time they dialogue with society at large. Why? Because today over 90 per cent of Brazilian population own a TV set and a big part of the middle-class subscribe to a newspaper. We realized then that we must have a dialogue with the press somehow, and in 2004 we created a network of MST communicators. (Solange, member in the National Leadership representing the communication sector)

From the interviews it is also possible to conclude that the view within the movement is that it is not possible to turn their backs on large media corporations because they, despite being controlled by the antagonist class, are important mediators of the movements' relation with society. Such a view of media illustrates the mediation process, through which the media are in-between (Couldry 2010) MST and society. The belief in this role outweighs the fact that Brazilian media corporations are seen as class antagonists and is behind the decision to establish ways to collaborate with certain media outlets.

This understanding of media as institutions (different from the understanding of media as technologies) and that these institutions represent class interests which contradict MST's worldview is at the root of their action as media activists. MST's struggle to reclaim media is thus not reduced to the representations of the movement but also to the redistribution of symbolic and material resources in Brazil. The demands of the movement include the revision of public concessions that allow private companies to operate radio and television stations, reformulation of the radio broadcasting law to facilitate the operations of community radios in rural areas, and stronger state regulation of digital communications to grant affordability and quality of access to rural populations. Such demands are not directly related to the primary demands of MST as a social movement but they put in evidence the importance of communication rights for the achievement of representation rights (Fraser 2009). As already discussed, MST has since its early days attempted to create arenas and channels for communication within the movement and beyond-with communities and the society at large. What sets MST apart from other activist organisations is the systematisation of their action in the area of democratisation of communication in 
parallel to their original cause. This systematisation takes place in various ways, from the establishment of media education programmes to joining the FNDC.

The interviews with militants involved in communication activities evidence that MST's main communication problem is not the lack of access to media as technologies (even if the lack of resources is also a problem in certain situations) but the overall unfavourable structure of the communication sector in Brazil. Thus, in order to be able to have a voice and symbolical recognition (Fraser 2009), MST is compelled to circumstantially direct their activism towards the area of media. MST's media activism, as well as militants' understandings of their role in promoting democratisation of communication in Brazil, will be discussed in the following section.

\section{Participation beyond Technologic Determinism}

This study departs from an understanding of participation as the capacity to act socially with a view to engage in public debates that take place in media and the aim to influence political agendas. As Carpentier (2009) argued, participation is not enough, but can be a path towards representation. The understanding of politics guiding the study resonates with a view of the political that extrapolates institutionalised and parliamentary politics (Carpentier 2011, 21). In the case of MST, the movement's demands (agrarian reform, limits to the power of agribusiness corporations) cannot be implemented at the institutional level without public debate. The problems arise when MST, a collective social actor representing those affected (Fraser 2009) by rural politics and policies, cannot participate in this debate with other actors in equal conditions. In light of recent developments and changes (technological, political, economic) in the media sector globally, it is necessary to engage in an informed discussion about how and if these developments change the conditions in which marginal actors such as social movements participate in the public debate about issues that affect them.

As discussed in the previous section, throughout its history the movement has been trying to gain space in the debate by means of creating its own media (newspaper, radio, audio-visual production). With the emergence and spread of the Internet from the end of the 1990s, the belief arose that digital media would facilitate social actors such as MST to participate in the public debate. Through digital communications they would be able to establish networks (Castells 2009) across geographical borders, and reach society without the mediation of large media corporations. Although civil society organisations have been investing time and resources in media training (Milan 2009a, 2009b; Léon, Burch, and Tamayo 2001) and in trying to incorporate new technologies (not only the Internet, but even older technologies when they were new) to their routines, the extent to which access to technologies determines participation in wider debates is still uncertain. In this sense, Carpentier $(2011,27-28)$ points out that there are differences between participation and access and interaction. He observes that access and interaction are usually integrated in the definition of participation, which "causes the link with the main defining component of participation, namely power, being obscured" $(2011,27)$. In the case of marginal and minority actors such as MST, this perspective would lead to an understanding that the access to technologies and the capacity to use them-enabling interaction, as was the case with the newspapers and the settlement radios and more recently with Internet access-would be a sufficient condition for participation. However, in the views of MST militants, access to 
technologies is not a sufficient condition for their participation in public debate as a collective actor:

... what we need in Brazil is a set of policies for communication that are truly public, in which social movements and all social groups can have spaces to communicate and we also need a "demonopolization" process, but this process cannot be a simple distribution: we will have a community radio but we will continue with Globo. This does not solve the problem, if we don't terminate the media monopoly. You can have one, two, three community radio stations, but you also have a mega conglomerate such as Bandeirantes, Globo, Record, who dominate the market. (Solange, member in the National Leadership representing the communication sector)

The analysis of the interviews points to a more complex relation between access technology and political participation. First, MST's involvement with media activism and the incorporation of these kinds of demands reveals that mediated communication is still an important arena of political participation. Second, it also shows that media as institutions still have prominent power in framing reality and defining the basis upon which certain subjects will be discussed. As an informant explained, even though MST was able to grant coverage during the organisation's sixth National Congress in February 2014, they did not have any control over how the event was framed:

[...] the newspapers, they did not report on our demands, they talked very little about our demands, which are agrarian reform, why we are demonstrating, MST's $30^{\text {th }}$ anniversary. Those who talked about that only gave us three minutes, five seconds, very short time. Most of the coverage was about the conflict that was when the police raided our demonstration because some 15 boys were taking materials out from a bus, for a theatre intervention. (Solange, member in the National Leadership representing the communication sector)

These findings show that there is a meso level of mediated interaction between that of the self-representation allowed by new media technologies and the participation in a broader arena of discussion afforded by the established media outlets that needs to be made visible. Media activism is located exactly at this level. It mediates between the access to media for self-representation and the access to the media as arenas of discussion. The findings also point out the need to consider political aspects of national media landscapes when analysing and discussing the potential of new media technologies and to see social actors and not technologies as the agents of social change.

Despite organised communication efforts during the National Congress in February 2014, which included a breakfast with the press, two press conferences and a dedicated team to accompany journalists, the extent to which the issues and agendas that MST wanted to raise were actually reported by the mainstream press was very limited-according to their own evaluation. This situation is not unique for the event, but characteristic of the relationship between MST and the mainstream press in Brazil as it was shown in the interviews and discussed in the previous section. This exemplifies the difficulties that certain established actors in society-in this case, one of the biggest social movements in Latin America-have difficulties in having their opinions and views reported by the media. The view from MST is that regardless of their efforts to influence journalistic agendas, there is already a frame in place that delegitimises social movements. Nevertheless, the movement keeps investing time, efforts and resources in trying to establish 
relations with media institutions of different sizes and political allegiances. This relationship is a testimony to the important role played by journalism on the side of movementproduced media in providing spaces for dialogue between social movements and the society.

Some scholars, however (for instance, Castells 2001; Jenkins 2006), argue that digital media could drastically change the balance of power between marginal groups and mainstream media due to its low entry barriers and collaborative and network-inducing features. In the case of MST, some advances have been noticed that are connected to the advent of digital media. Nevertheless, there is an awareness of structural conditions that cannot be changed by the use of digital media alone:

If we consider our official channels, we are advancing a little. For example through our Twitter we are being able to form the public opinion at times, more than simply reproduce content that we have in our website. We had also other experiences like the blog, a pro agrarian reform blog, when MST was subject of a parliamentary investigation and we formed a network of communicators and a Twitter account. Recently, particularly when the internet and social networks gained a big potential, especially among youth, we have been looking into this potential that we have to put agrarian reform in the public agenda through this medium. Our task is to make the most of this potential to establish a dialogue with the society, but we must not forget that our action continues on the streets. (Mayrá, press-officer)

On Facebook, because it is a space where we don't have the editorial filter or the ideological filter, which is the filter in the monopolized mass media, we were able to express the magnitude of our demonstration, why we demonstrated. So I think that at this moment the social networks have a very important role, contributing in the sense of making the counter-information to mainstream media. However, we cannot fool ourselves that we are going to solve the problem only with the social networks because we also need to fight with counter-information against these big media, because they are public concessions, they also need to hear our side, they need to stop with this coverage that criminalizes [us]. (Solange, member in the National Leadership representing the communication sector)

These opinions and analyses show that the advantages of using digital mediabroadcasting to a wider audience, capacity of quickly mobilising networks of supporters and sympathisers, improving internal communication and circulation of information among militants-are not credited to the medium itself but to organisational routines and structures that facilitate the appropriation of digital media. Another important aspect, captured in these fragments, is the awareness that access to the technologies and capacity to produce content, albeit important, is not going to operate changes in the long run.

From this realisation that the possibilities of entering public debate through the communication channels established and controlled by the movement and sympathisers are limited, MST started to direct their action also to media activism. Media activism for MST is a way to ensure that, apart from having access to material resources and technologies, the movement will also benefit from a more varied media environment in which the interests of elite groups do not obstruct journalistic activity. Around 2012 MST started a more active participation in the FNDC, a pool of civil society organisations that promotes a variety of actions with a view to change the political economic structure of media landscape 
in Brazil. The FNDC main campaign focus is the operationalisation and enforcement of directives stated in the 1988's Federal Constitution that can prevent the formation of oligopolies and monopolies. ${ }^{10}$ The organisation also advocates stronger public control and state regulations over digital communications to counterbalance the power of large corporations in the sector. From this perspective, an updated broadcast legislation that facilitates the establishment of community radios in rural areas, public subsidies that foster a more diverse media landscape and the institution of a regulatory authority for the media sector would bring more long-term and structural benefits to MST (and similar social actors) than simple access to Internet and mobile technologies. This does not diminish the importance of technologies for marginal social actors, but highlights structural conflicts in the socio-political reality in which technologies are an aspect.

The process through which MST becomes a media activist invites us to problematise initiatives that focus only on facilitating a limited kind of participation in media that does not come with the possibility of representation in the public sphere. In order to play a role in a democratic society, mediated communication should not be understood as the mere broadcasting of messages. Those with the ability and the resources to speak to a public, which become more easily available with the emergence of digital media and new media technologies, might still not be able to communicate and participate in a discussion due to uneven distribution of power and resources. For this reason, communication power should always be evaluated in relation to the extent to which different groups (and their positions) who are affected by political decisions are represented in the media. The interviews with MST militants show that the kind of self-expression and self-representation allowed by media is valued by MST, but also that they recognise the limitations of these endeavours. Through the analysis of MST's case we can question the political limitations of the network concept (Castells 2009) and argue for more politically grounded analyses of the role of media for marginal actors.

\section{Final Discussion}

This article aimed to discuss the possibilities and limitations brought by digital media to the action of marginal social actors through the analysis of the Brazilian Landless Workers Movement (MST). Through interviews with MST militants working with communication it is possible to question views that digital media alone are conducive of structural change for marginal social actors. The case of MST supports the argument that social participation through communication is more a socio-political question than a technological question. Whilst movement militants acknowledge certain advantages brought by digital media platforms such as Facebook, they also argue that the benefits are limited and continue to act for structural changes in the media system. Albeit a particular case, the case of MST is not only an anecdotal account but an example that speaks for the need to look for answers to questions regarding media, democracy and social participation in a macro-perspective that is attentive to the position of social actors in the socio-political landscape. This particular account must be followed by more studies that investigate the roles of media for marginal social actors from a macro perspective in order to develop a contemporary social theory of the relation between media, democracy and social participation.

Considering the findings of this study, I argue that studies which look into the experiences of established and autonomous social actors (as opposed to social interventions 
promoted by aid organisations) in emergent democracies and developing countries are of crucial importance to counterbalance recent focus on digitally enabled activist action that overlooks more continuous and longstanding activism. Such organisations are usually established social actors with a clear working agenda and demands, and tend to have a reflexive relation to media. Accounting for the experiences of such organisations complements and diversifies the knowledge constructed by the analyses of technologyenabled individual activism, which has gained strong weight as the empirical object for studies of the relationship between technology and participation. My argument with this study is that collective action and the promotion of structural change are still relevant, even in a time where many are able to express their discontentment through digital media. Collective action and structural change are difficult to grasp, however, with shortterm studies of ephemeral protest action and individual engagement with technology. In order to have an in-depth understanding of these processes it is necessary to look into varied forms of social organising, of which established and autonomous marginal social actors as MST are an under-represented example. I hope to have shown with this study that this kind of insurgent organisation can offer important insights into theory building in the field of media and democracy.

Recent studies have demonstrated successfully how digital social media platforms facilitate episodic and performative forms of action (Tufekci and Wilson 2012; Bennett and Segerberg 2012). However, the impact of these actions and the kinds of long-term social change they may set in motion can only be accessed by research that looks at the macro level of representation (Fraser 2009) and not only into the micro level of participation. Moreover, borrowing Carpentier's (2007) terms, a strong focus on participation in the media-those media in which participation is allowed-can overshadow the analysis of more complex participation through the media-in the mainstream media-that requires structural change. In order to understand the macro level of representation and participation through the media we should bring communication, understood as a social and political process, back to the analyses. The struggle to communicate, experienced by MST, goes beyond the production and circulation of messages and involves being capable, as a social actor, to articulate a dialogue with other sectors of society and to be seen as a legitimate source and subject in the discussions about the issues that affect the movement and militants. This is a clear communication question that deals with how the power and the right to communicate are seen and distributed and how media artefacts and institutions serve as instruments for exerting the power and exercising the right to communicate.

Yet another angle of the discussion is the ethnocentric character of current debates about media and social participation. A large amount of studies in the Euro-American geographical context have explored the views and practices of northern-based contemporary social unrest and protest in which access and knowledge are not individual barriers and where the media landscape has different contours, compared with many developing countries. Also the problems of representation that affect postcolonial countries in the Global South require theorisation and analytical tools that are attentive to historical and structural political conditions in these areas. Whereas much of contemporary social action in the West-North is fuelled by loss of rights and material resources, social action in the Global South-of which MST is an example-arises from never having had rights. This difference will be crucial for understanding how media practices take shape in this kind of formation. 


\section{DISCLOSURE STATEMENT}

No potential conflict of interest was reported by the author.

\section{NOTES}

1. For a comprehensive overview of alternative media theories, see Jeppesen (2015).

2. Fuchs and Sandoval $(2009,146)$ argue instead that "critical content should be considered as minimum requirement for defining alternative media", which need not be alternative "at the level of economic product form" or at the level of "production processes".

3. For an analytical overview of definitions and notions of alternative media, see Atton (2002, 8-23).

4. See the Reporters Without Borders 2013 report "Brazil, The Country of 30 Berlusconis". Accessed October 23, 2014. http://issuu.com/rsf_webmaster/docs/brazil_eng?e=0

5. Participation through the media, according to Carpentier (2007), is the process through which different groups have issues of concern covered by media and are heard as sources. It differs from participation in the media, which defines the direct participation of the community in managing media outlets.

6. Popular here has a different meaning than in English-speaking literature where popular is usually connected to mass culture. Popular in this context means something related to the popular classes.

7. For example, changes in the school schedule, distribution of seeds, opening times at the local healthcare centre and times for vaccinations.

8. During the 1990s there was more acceptance for MST's activities, following a change that can be related to the advancement of right-wing neoliberal governments in the country. At the beginning of the twenty-first century, mainstream media outlets tended to ignore and ostracise the movement as a political actor.

9. Globo Communications and Participations, the holding that operates, among other companies, Globo TV, is also a member of the Brazilian Agribusiness Association (ABAG).

10. Current media legislation-Código Brasileiro de Telecomunicações—was sanctioned in 1962 and does not establish the activity of a regulatory body as is common in European countries (e.g. the Office of Communications [Ofcom] in the United Kingdom). The Brazilian Federal Constitution from 1988 established important guidelines such as the prohibition of monopolies and oligopolies, but these have not been ratified so that the guidelines can become actual regulations.

\section{REFERENCES}

Atton, Chris. 2002. Alternative Media. London: Sage.

Atton, Chris, and James F. Hamilton. 2008. Alternative Journalism. London: Sage.

Bennett, W. Lance, and Alexandra Segerberg. 2012. "The Logic of Connective Action: Digital Media and the Personalization of Contentious Politics." Information, Communication and Society 15 (5): 739-768.

Berger, Peter, and Thomas Luckman. 1967. The Social Construction of Reality-A Treatise in the Sociology of Knowledge. New York: Doubleday. 
Carpentier, Nico. 2007. "Four Approaches to Alternative Media." In Understanding Alternative Media, edited by Olga G. Bailey, Bart Cammaerts, and Nico Carpentier, 3-34. New York: Open University Press.

Carpentier, Nico. 2009. "Participation Is Not Enough: The Conditions of Possibility of Mediated Participatory Practices." European Journal of Communication 24 (4): 407-420.

Carpentier, Nico. 2011. "The Concept of Participation: If They Have Access and Interact, Do They Really Participate?" CM-časopis za upravljanje komuniciranjem 6 (21): 13-36.

Castells, Manuel. 2001. The Internet Galaxy. London: Oxford University Press.

Castells, Manuel. 2009. Communication Power. Oxford: Oxford University Press.

Couldry, Nick. 2010. "Theorising Media as Practice." In Theorising Media and Practice, edited by Birgit Bräuchner and John Postill, 35-55. New York: Berghahn Books.

Couldry, Nick. 2012. Media, Society, World: Social Theory and Digital Media Practice. London: Polity.

Curran, James, Natalie Fenton, and Des Freedman. 2012. Misunderstanding the Internet. London: Routledge.

Deane, James. 2007. "Democratic Advance or Retreat? Communicative Power and Current Media Developments." Global Civil Society 8: n.p.

de Jong, Wilma. 2005. "The Power and Limits of Media-based International Oppositional Politics -A Case Study: The Brent Spar Conflict." In Global Activism, Global Media, edited by Wilma de Jong, Martin Shaw, and Neil Stammers, 110-124. London: Pluto Press.

DeLuca, Kevin M., Ye Sun, and Jennifer Peeples. 2011. "Wild Public Screens and Image Events from Seattle to China: Using Social Media to Broadcast Activism Beyond the Confines of Democracy." In Transnational Protests and the Media, edited by Simon Cottle and Libby Lester, 143-158. New York: Peter Lang.

Downing, John D. 2000. Radical Media-Rebelious Communication and Social Movements. Thousand Oaks, CA: Sage.

Fraser, Nancy. 2009. Scales of Justice-Reimagining Political Space in a Globalizing World. New York: Columbia University Press.

Fuchs, Christian. 2010. "Alternative Media as Critical Media." European Journal of Social Theory 13 (2): 173-192.

Gaber, lan, and Alice Wynne Willson. 2005. "Dying for Diamonds: The Mainstream Media and NGOs-A Case Study of ActionAid." In Global Activism, Global Media, edited by Wilma de Jong, Martin Shaw, and Neil Stammers, 95-109. London: Pluto Press.

Gavin, Neil T., and Tom Marshall. 2011. "Climate Change and International Protest at Copenhagen: Reflections on British Television and the Web." Transnational Protests and the Media, 197212. New York: Peter Lang.

Gitlin, Todd. 1980. The Whole World Is Watching: Mass Media in the Making and Unmaking of the New Left. Oakland: University of California Press.

Gramsci, Antonio. 1971. Selections from the Prison Notebooks. Translation by Q. Hoare and G. N. Smith. New York: International Publishers.

Gumucio-Dagron, Alfonso. 2001. Making Waves: Stories of Participatory Communication for Social Change. New York: Rockefeller Foundation.

Halloran, James D., Philip R. C. Elliott, and Graham Murdock. 1970. Demonstrations and Communication: A Case Study. London: Penguin Books.

Jenkins, Henry. 2006. Convergence Culture: Where Old and New Media Collide. New York: NYU Press.

Jeppesen, S. 2015. "Theorizing Alernative Media: From Content and Structure to Ideology and Power." Paper presented at the 65th ICA Conference, San Juan, Puerto Rico, 2015. 
Léon, Osvaldo, Sally Burch, and Ernesto Tamayo. 2001. Movimientos Sociales en la Red. Agencia Latino Americana de Información. Accessed October 4, 2012. http://alainet.org/publica/ msred/msr-web.pdf

McChesney, Robert W. 2013. Digital Disconnect: How Capitalism Is Turning the Internet Against Democracy. New York: The New Press.

Milan, Stefania. 2009a. "Communication for Development in Practice: A Four-step Path to Implement Community Media Needs in Development Projects." Development in Practice 19 (4\&5): 598-609.

Milan, Stefania. 2009b. "Community Media Activists in Transnational Policy Arenas: Strategies and Lessons Learnt." In Understanding Community Media, edited by Kevin Howley, 308-317. Thousand Oaks, CA: Sage.

Milan, Stefania. 2013. Social Movements and Their Technologies: Wiring Social Change. Thousand Oaks, CA: Palgrave Macmillan.

Morozov, Evgeny. 2012. The Net Delusion-How Not to Liberate the World. London: Penguin Books.

Mosco, Vincent. 2005. The Digital Sublime-Myth, Power and Cyberspace. Cambridge, MA: MIT Press.

Peruzzo, Cicília M. 2007. "Direito à comunicação comunitária, participação popular e cidadania" ["Right to Community Communication, Popular Participation, and Citizenship"]. Lumina 1 (1): 1-29.

Peruzzo, Cicília M. 2014. "Communication in Social Movements: A New Perspective in Human Rights." In Reclaiming the Public Sphere: Communication, Power and Social Change, edited by Tina Askanius and Liv Stubbe Ostergaard, 67-183. Thousand Oaks, CA: Palgrave Macmillan.

Shannon, Claude E., and Warren Weaver. 1949. A Mathematical Theory of Communication. Urbana: University of Illinois Press.

Rodríguez, Clemencia. 2001. Fissures in the Mediascape: An International Study of Citizens' Media. New York: Hampton Press.

Rodriguez, Clemencia. 2003. "The Bishop and His Star: Citizen's Communication in Southern Chile." In Contesting Media Power, edited by N. Couldry and J. P Curran. London: Rowman and Littlefield.

Rodríguez, Clemencia. 2011. Citizens' Media against Armed Conflict: Disrupting Violence in Colombia. Minneapolis: University of Minnesota Press.

Sandoval, Marisol, and Fuchs, Christian. 2010. "Towards a Critical Theory of Alternative Media." Telematics and Informatics, 27 (2): 141-150.

Silverstone, Roger. 2007. Media and Morality: On the Rise of the Mediapolis. Cambridge: Polity Press.

Tufekci, Zeynep, and Christopher Wilson. 2012. "Social Media and the Decision to Participate in Political Protest: Observations from Tahrir Square." Journal of Communication 62 (2): 363-379.

Williams, Raymond. 2003. Television-Technology and Cultural Form. London: Routledge.

Wolfsfeld, Gadi. 2004. Media and the Path to Peace. Cambridge: Cambridge University Press.

Zhao, Yuezhi. 2003. "Falun Gong, Indentity, and the Struggle Over Meaning Inside and Outside China." In Contesting Media Power: Alternative Media in a Networked World, edited by Nick Couldry and James Curran, 209-226. Lanham, MD: Rowman and Littlefield Publishers.

Paola Sartoretto (corresponding author) is an Associated Researcher in the Institute of Latin American Studies at Stockholm University, Stockholm, Sweden. Email: paola. sartoretto@lai.su.se. 